11 Bradbury RC, Stearns FE, Steen PM. Interhospital variations in admission severity-adjusted hospital mortality and morbidity. Health Serv Res 1991;26:407-24.

12 Al-Haider AS, Wan TTH. Modelling organizational determinants of hospital mortality. Health Serv Res 1991;26:303-23.

13 Park RE, Brook RH, Kosecoff J, Keesey J, Rubenstein L, Keeler E. Explaining variations in hospital death rates, randomness, severity of illness, quality of care. JAMA 1990;264:484-90.

14 Iezzoni LI, Ash AS, Shwartz M, Daley J, Hughes JS, Mackiernan YD. Judging hospitals by severity-adjusted mortality rates: the influence of the severity-adjustment method. Am J Public Health. 1996;86:1379-87.

15 Iezzoni LI. The risks of risk adjustment. JAMA 1997:278:1600-7.

16 Goss MEW, Read JI. Evaluating the quality of hospital care through severity adjusted death rates: some pitfalls. Med Care 1974;12:202.

17 Thomas JW, Holloway JJ, Guire KE. Validating risk-adjusted mortality as an indicator for quality of care. Inquiry 1993;30:6-22.

18 Hartz AJ, Gottlieb MS, Kuhn EM, Rimm AA. The relationship between adjusted hospital mortality and the results of peer review. Health Serv Res 1993;27:765-77

19 Lipworth L, Lee JAH, Morris JN. Case fatality in teaching and nonteaching hospitals, 1956-1959. Lancet 1963;i:71.

20 Palmer HR, Reilly MC. Individual and institutional variables which may serve as indicators of quality of medical care. Med Care 1979;18:693-717.

21 Luft HS, Hunt SS. Evaluation of individual hospital quality through outcome statistics. JAMA 1986;255:2780.

22 Hartz AJ, Krakauer H, Kuhn EM, Young M, Jacobsen SJ, Greer G. Hospital characteristics and mortality rates. N Engl J Med 1989;321:1720-5.

23 Department of Health. Hospital episode statistics. England: financial years 1991-92, 1992-93, 1993-94 and 1994-95.London: DoH, 1993-1996.

24 Office of Population Censuses and Survevs. 1991 census definitions. Great Britain. London: HMSO, 1992

25 Dale A, Marsh C, eds. The 1991 census users guide. London: HMSO, 1993.

26 NHS Executive. Hospital and ambulance services: the patient's charter comparative performance guide 1993-1994. London: Department of Health, 1995.

27 Department of Health. Waiting times for first outpatient appointments in England: quarter ended 30 September 1994. Statistical bulletin 1995/3. London: DoH, 1995.

28 Department of Health. GMS (general medical services) GMP (general medical practitioner) census. London: $\mathrm{DoH}, 1997$.

29 Bruster S, Jarman B, Bosanquet N, Weston D, Erens R, Delbanco TL. The patient's view - a national survey of hospital patients. BMJ 1994;309:1542-6.

30 Jarman B. Underprivileged areas: validation and distribution of scores. BMJ 1984;289:1587-92.
31 Townsend P, Phillimore P, Beattie A. inequalities in health in the Northern region. Bristol: Northern RHA, University of Bristol, 1986.

32 Carstairs V, Morris R. Deprivation and health in Scotland. Aberdeen: Aberdeen University Press, 1991

33 Office of Population Censuses and Surveys. Classification of occupations 1980. London: HMSO, 1980

34 Greenfield S, Aronow HU, Elashoff RM, Watanabe D. Flaws in mortality data: the hazards of ignoring comorbid disease. JAMA 1988;260:2253-5.

35 Green J, Wintfeld N, Sharkey P, Passman LJ. The importance of severity of illness in assessing hospital mortality. JAMA 1990;263:241-6.

36 Dicing with death rates (editorial). Lancet 1993;341:1183-4.

37 Orchard C. Comparing health care outcomes. BMJ 1994;308:1493-6.

38 McKee M, Hunter D. Mortality league tables: do they inform or mislead? Qual Health Care 1995;4:5-12.

39 Goldfarb MG, Coffey RM. Case mix differences between teaching and non-teaching hospitals. Inquiry 1987;24:68-84.

40 Charlson ME, Pompei P, Ales KL, MacKenzie CR. A new method of classifying prognostic comorbidity in longitudinal studies: development and validation.J Chron Dis 1987;40:373-83.

41 Orchard C. Measuring the effects of casemix on outcomes. J Eval Clin Pract 1996;2:111-21.

42 Royston JP. A simple method for evaluating the Shapiro Francia W test for non-normality. Statistician 1983;32:297-30.

43 Royston P, Altman DG. Regression using fractional polynomials of continuous covariates: parsimonious parametric modelling (with discussion) Appl Stat 1994;43:429-67.

44 Vincent C. Framework for analysing risk and safety in clinical medicine. BMJ 1998;316:1154-7.

45 OECD. Health data-a comparative analysis of 29 countries. Paris: OECD, 1998.

46 Kassirer JP. Hospitals, heal yourselves. N Engl J Med 1999;340:309-10.

47 Goldstein H, Spiegelhalter DJ. League tables and their limitations: statistical issues in comparisons of institutional performance (with discussion) JR Stat Soc A 1996;159:385-443.

48 Roemer MR, Friedman JW. Doctors in hospitals: medical staff organization and hospital performance. Baltimore: Johns Hopkins University, 1971.

49 Selker HP. Systems for comparing actual and predicted mortality rates: characteristics to promote co-operation in improving hospital care. Ann Intern Med 1993;118:820-2.

50 NHS Executive. 'Faster access to modern treatment': how NICE appraisal will work. London: Department of Health, 1999.

51 McKee M. Indicators of clinical performance. BMJ 1997;315:142.

(Accepted 19 May 1999)

\title{
Trends in the use of the Mental Health Act: England, 1984-96
}

\author{
Sharon Wall, Matthew Hotopf, Simon Wessely, Rachel Churchill
}

Department of Psychological Medicine, Guy's, King's College, and St Thomas's School of Medicine and the Institute of Psychiatry, London SE5 8AZ

Sharon Wall, research worker Matthew Hotopf, senior lecturer in psychological medicine Simon Wessely, professor of liaison and epidemiological psychiatry

Section of Epidemiology and General Practice, Institute of Psychiatry, London SE5 8AF

Rachel Churchill, lecturer in psychiatric epidemiology

Correspondence to: Dr Hotopf m.hotopf@ iop.bpmf.ac.uk

BMJ 1999;318:1520-1
The Mental Health Act 1983 provides legislation to ensure a consistent and comprehensive approach to the compulsory admission of psychiatric patients in England and Wales. Since the introduction of the act, the provision of service has changed: hospitals have closed and the care in the community programme has been introduced. Despite the reduction in the number of psychiatric beds available Department of Health data show a rise in the absolute number of compulsory admissions. ${ }^{1}$ We aimed to determine the proportion of all psychiatric admissions that these compulsory "formal" admissions represent.

\section{Methods and results}

The Department of Health collects data from health authorities on compulsory psychiatric admissions, and these data were used to determine the proportion of all psychiatric admissions that were compulsory. Between 1984 and 1986 these data were presented for each calendar year. Since 1987 they have been presented for each financial year. Data were available from the Mental Health Enquiry from 1984 to 1986 and from the hospital episodes statistics system from 1989 to 1996. This system holds details of inpatients in NHS hospitals in England. Using these sources we calculated the proportion of all admissions to psychiatric hospitals that occurred under the act. Data on the total number of psychiatric admissions were not available for 1987-9.

The total number of compulsory admissions has almost doubled, rising from 13488 in 1984 to 24639 in 1995-6. The number of all psychiatric admissions rose from 190389 to 213240 over the same period. Therefore, the proportion of psychiatric admissions made under the act has risen from 7\% in 1984 to $12 \%$ in 1995-6 (figure).

\section{Comment}

There was a rise in the total number of admissions from 1984 to 1996, with increases in both the absolute number and the proportion of compulsory admissions. The quality of these data depends on accurate reporting by hospitals. There was discontinuity in the total number of admissions in 1986-9; in fact, they dropped slightly. We are unsure why this was so. It is possible that the data were collected in different ways and the change was artefactual. However, the number of compulsory admissions increased each year. Although the data that comprise the denominators were not ideal, as they came from two sources, the proportion of compulsory admissions increased steadily. 


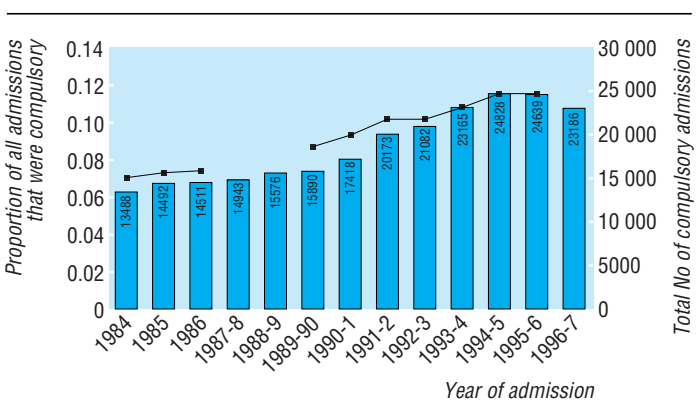

Bars represent the total number of compulsory psychiatric admissions to NHS facilities and the line represents the proportion of all admissions that were compulsory in England, 1984-96. Data on compulsory admissions not available for 1987-9

For 1989-96, when only one source of data was used for the denominator, the trend remained constant.

What explanations are there for the increase in compulsory admissions? Firstly, these changes may be due to alterations in the presentation of patients with psychiatric disorders. For example, there is some evidence that a higher proportion of psychiatric patients misuse drugs and alcohol, and this may lead to more florid presentations of psychotic illness. ${ }^{2}$ Secondly, changes in the availability of beds during this period may have increased the threshold for admission and decreased the threshold for discharge. Between 1982 and 1992, approximately 43000 fewer psychiatric hospital beds were available, ${ }^{3}$ and in inner city areas bed occupancy remains above $100 \%$ much of the time. The public's fear of violence by mentally ill patients and pressures to keep patients in hospital until it is "safe" to discharge them put further strain on the avail- ability of beds. Delays in admission and treatment caused by bed shortages may mean that patients' illnesses are becoming more severe and that compulsory treatment is being initiated in cases in which informal admissions would previously have been possible.

These results have implications for resources in terms of costs and staffing. Compulsory admissions are more time consuming since they generally require that patients be assessed by two doctors and a social worker. Disturbed patients also require more intensive nursing and supervision. Patients admitted under the act have the right to appeal, and mental health tribunals are time consuming and costly. We suggest that the move to community care may have led to a paradoxical and unexpected increase in the use of coercion in the treatment of patients with mental illnesses.

Contributors: $\mathrm{MH}, \mathrm{RC}$, and S Wessely developed the original protocol and obtained funding. S Wall obtained and analysed the data, and wrote the article. MH, RC, and S Wessely supervised this work and made comments on earlier drafts. $\mathrm{MH}$ is guarantor for the paper.

Funding: Department of Health. The views expressed in this paper are those of the authors and not necessarily those of the Department of Health.

Competing interests: None declared.

1 Department of Health. Inpatients formally detained in hospitals under the Mental Health Act 1983 and other legislation. London: DoH, 1998.

2 Cuffel B. Prevalence estimates of substance abuse in schizophrenia and their correlates. J Nerv Ment Dis 1992;180:589-92.

3 Davidge M, Elias S, Jayes B, Wood K, Yates J. Survey of English mental illnes. hospitals. Birmingham, Health Services Management Centre, University hospitals. Birmingham, Health Services Management Centre, Unive
of Birmingham, 1994. [Prepared for the Mental Health Task Force.]

4 Johnson S, Ramsay R, Thornicroft G, Brooks L, Lelliot P, Peck E, et al. London's mental health:the report to the King's Fund London Commission. Rev ed. London: King's Fund, 1998.

(Accepted 19 January 1999)

\section{Drug points}

\section{Aseptic meningitis after treatment with} amoxicillin

W Czerwenka, C Gruenwald, D Conen, Department of Internal Medicine, Canton Hospital, CH-5001 Aarau, Switzerland

The development of aseptic meningitis has been associated with various drugs-for example, non-steroidal anti-inflammatory drugs, ranitidine, carbamazepine, vaccines against hepatitis B and mumps, immunoglobulins, co-trimoxazole, and penicillin. ${ }^{1-5}$ We report a case of aseptic meningitis after treatment with amoxicillin.

A 76 year old woman was admitted to our hospital with fever, headache, and neck stiffness. Five days before admission she had had a pretibial wound treated with amoxicillin-clavulanic acid. Long term treatment with aspirin, enalapril, and levothyroxine (thyroxine) had not been changed in the previous month. Two days before admission she had developed fever, headache, and neck ache.

On admission her general condition was poor, but findings on physical examination were normal except for neck stiffness. All laboratory findings were within the normal range. Cerebrospinal fluid showed pleocytosis with 63 cells (62 monocytes) and a slightly raised protein concentration of $0.47 \mathrm{~g} / 1 \quad(0.15-0.45 \mathrm{~g} / \mathrm{l})$. No microorganisms were found. She recovered with treatment of symptoms.

From her history we knew of two similar episodes in 1992 and 1995. Twelve and 6 days respectively after the initiation of antibiotic treatment with amoxicillin (with and without clavulanic acid), she had been admitted to our hospital with the same symptoms of fever, headache, and neck stiffness. Cerebrospinal fluid had been examined during the first admission and also showed pleocytosis with 40 cells (38 monocytes) without an increase in protein concentration. No bacterial micro-organisms or serological signs of neurotropic viral infections had been found.

On the basis of these three confirmed episodes of meningitis after recurrent exposure to amoxicillin, with and without clavulanic acid, with repetitive negative testing for viral, bacterial, and mycobacterial micro-organisms, we diagnosed aseptic meningitis induced by amoxicillin. To our knowledge, this is the first well documented publication of such a severe side effect of a commonly used antibiotic.

The exact mechanism for the development of aseptic meningitis induced by drugs is not known, although hypersensitivity reactions and immunological mechanisms have been suggested. ${ }^{5}$

1 Weksler BB, Lehany AM. Naproxen-induced recurrent aseptic meningitis. Drug Intelligence and Clinical Pharmacy 1991;25:1183-4.

2 Dang CT, Riley DK. Aseptic meningitis secondary to carbamazepine therapy. Clin Infect Dis 1996;22:729-30.

3 Durand JM, Suchet L. Ranitidine and aseptic meningitis. BMJ 1996;312:886.

4 Sekul EA, Cupler EJ, Dalakas MC. Aseptic meningitis associated with high-dose intravenous immunoglobulin therapy: frequency and risk factors. Ann Intern Med 1994;121:259-62.

5 River Y, Averbuch-Heller L, Weinberger M, Meiner Z, Mevorach D, Schlesinger I, et al. Antiobiotic induced meningitis. J Neurol Neurosurg Psychiatry 1994;57:705-8. 